\title{
Attitudinal Study of User and Non-User Teachers' towards ICT in Relation to Their School Teaching Subjects
}

\author{
Chhavi Lal \\ Assistant Professor, Dept. of Pedagogical Science, Faculty of Education, Dayalbagh Educational Institute (Deemed \\ University),Dayalbagh, Agra-5, U.P., India \\ *Corresponding author: clsingh2009@rediffmail.com
}

Copyright (C) 2014 Horizon Research Publishing All rights reserved.

\begin{abstract}
The present study aimed to know the attitude towards ICT of user and non-user teachers of ICT. The data were collected from 40 (20 male and 20 Female) user and non-user of ICT secondary school teachers from Agra city. Attitude towards ICT was measured by Computer Attitude Scale (CAS), originally developed by Loyd and Gressard (1984). Data were treated by Mean, SD and t-test. The findings of study reveal that the ICT user teachers' attitude towards ICT is highly positive in comparison to ICT non-user teachers but they have also positive attitude towards ICT in relation to their school teaching subjects. It is clear that vast majority of secondary school teachers have positive attitude towards ICT in relation to their school teaching subjects for many reasons. Other important findings are also discussed.
\end{abstract}

Keywords ICT, User and Non-user Teachers of ICT

\section{Introduction}

The relatively recent introduction of new technology into mainstream schooling was widely expected to penetrate and transform teaching and learning across the curriculum. The term ICT encompasses the range of hardware (desktop and portable computers, projection technology, calculators, data logging and digital recording equipment), software applications (generic software, multimedia resources) and information systems (Intranet, Internet) available in schools at the time of the research. Usage of ICT in schools is so diverse that it is almost impossible to list all possible applications. Taylor $(1980,2003)$ recognized three roles of computers in a classroom: as tutor, tool, and tutee. Introduction of ICT in biology lessons can raise not only level of knowledge but students attitudes toward biology as well (Haunsel and Hill, 1989; Kubiatko and Halakova, 2009).

Ability to work with information and communication technologies (ICT) is recognized as one of the key competencies necessary for success in life and competition in the labour market (Levy and Murmane, 2001; Salganik, 2001; Eurydice, 2002) which every citizen should possess (Recommendation of the European Parliament and of the Council, 2006), and term 'computer literacy' was introduced to distinguish between users and non-users of ICT (Bawden, 2001). Concerning ICT, two important roles are assigned to schools. The first is to fulfil the expectations of society for demanding ICT skills, and the second is to raise the quality of education in the schools with the support of ICT. Many scholars, teachers and teacher-trainers have recognized the potential of ICT to enhance teaching and learning, and as a side effect the number of published articles about the use of ICT in school work is enormous (Bell and Bell, 2003). However, despite significant investment in training and resources, in reality schools are still far below the level of ICT use in science, transport, communication, industry, and many other fields (Hawkins 2002; Hepp, Hinostroza, Laval and Rehbein 2004; Machin, McNally and Silva, 2007; Eteokleous, 2008).

Today face of classroom is changing. The teachers should prepare to keep up with technology utility in the classroom. ICT is not only an essential tool for teachers in their day-to-day work, but also offers them opportunities for their own professional development. In conventional teaching, most of the time is consumed for input output and less time left for process, but in teaching with ICT, the input, output time is reduced, and process time increased. When the process time is increased, the time of student's activities, discussion, correlation with other subject brainstorming, learning etc. will increase phase, which is more important in a period of 45 minutes or hour. ICT may play potential role in revitalizing education to meet growing aspiration of today's world. ICT as a powerful tool can be employed flexibly to support new pedagogic approach, one that moves away from knowledge delivery to involving pupils more actively in engaging with scientific ideas and developing skills. 
It is again justified that just by installing various technologies in schools and classrooms would not ensure its effective integration in teaching learning process, we need to know the attitude of the teachers in relation to integrate technology in their classroom. The teacher's attitude towards the new technology plays vital role in using or not using technology in their school teaching subjects. Thus, the above study is designed to consider the above problems in the Indian context.

\subsection{Emergence and Justification of the Problem}

India to compete and excel in this global community, our young people need to develop the understanding, the skills and master the attributes that will serve them well in this knowledge era. The teachers are the effective medium who will acquaint the students to the changing information arena. For this the teachers themselves need to be familiar and well acquainted with the upcoming technologies. The way teachers view new technology, how they respond to it and how they present it and how it helps to accomplish their vision of teaching and learning, will affect future years of educational technology implementation in our classrooms. Each individual is unique with unique needs and a unique way of learning. Each is therefore entitled to an individualized way of learning. This is not possible in a conventional classroom where the average is addressed.

ICT has the potential to transform learning in and beyond the classroom. Some of the perceived benefits to Teachers are in the:

$>$ Teaching

$>$ Sharing of Resources

$>$ Professional Development

$>$ Increasing Accessibility

$>$ Human Resources Development

$>$ Total Quality Management

In today's time, it is not possible to achieve above-mentioned objectives only by the chalk and talk method. In the period of globalization, ICT becomes the powerful tool to communicate our ideas and information with rest of the world. It is easily shared by the common man. ICT allow us, to have anytime access to the information and at anywhere. Teachers' plays very prominent role in molding up tomorrow's citizen, the teachers should possess training in using the most modern technologies in the field of education. So, the attitude of teachers is very important as it is a tendency which helps them to be favourable or unfavourable towards the usage of most modern technology in the field of teaching. For teaching any subject, there cannot be one best method chosen for teaching a subject or topic depends on the nature of the content, level of understanding of the learning etc.

Thus, the question arises in the researcher's mind that what change comes in the attitude of teachers who use the ICT in their effective teaching. To know the answer this question researcher takes the problem.

\section{Objectives of the Study}

The objectives of the present study can be expressed as following:

1. To study the attitude of ICT user and non-users Teachers' towards ICT in relation to their School teaching subjects.

2. To compare the attitude of ICT user and non-user Teachers towards ICT in relation to their School teaching subjects.

3. To compare the attitude of male and female ICT user and non-users Teachers towards ICT in relation to their School teaching subjects.

4. To compare the attitude of male ICT user and non-user Teachers towards ICT in relation to their School teaching subjects.

5. To compare the attitude of female ICT user and non-user Teachers towards ICT in relation to their School teaching subjects.

\section{Hypotheses of the Study}

In relation to the above-mentioned objectives, the hypotheses can be formulated as following:

1. There is no significant difference between the attitude of ICT user and non-user teachers towards ICT in relation to their school teaching subjects.

2. There is no significant difference between the attitude of male and female ICT user teachers towards ICT in relation to their school teaching subjects.

3. There is no significant difference between the attitude of male and female ICT non-user teachers towards ICT in relation to their school teaching subjects.

4. There is no significant difference between the attitude of male ICT user and non-user teachers towards ICT in relation to their school teaching subjects.

5. There is no significant difference between the attitude of female ICT user and non-user teachers towards ICT in relation to their school teaching subjects.

\section{Design of the Study}

The Design of the study can be stated under the following heads:

\subsection{Method of the Study}

Keeping in view the objective and nature of the study, the descriptive survey method was adopted by the researcher.

\subsection{Population}


Population is the totality or aggregate of the individuals from which inference is drown in a study. Population of the present consists of the entire various secondary school Teachers of Agra city.

\subsection{Variables of the Study}

- Independent Variables - ICT

- Dependent Variables - Attitude

\subsection{Sample of the Study}

Multi stage stratified random sampling technique was adopted in order to select the male and female, user and non-user of ICT secondary school teachers from Agra city to collect the relevant data. The total sample was 40 (20 male and 20 Female) ICT user and non-user teachers.

\subsection{Tools and Techniques Used in Study}

The researcher to know teachers attitude towards information and communication technology in their school teaching subjects was used standardized tool i.e. Computer Attitude Scale (CAS), originally developed by Loyd and Gressard (1984). Because Loyd and Gressard (1985) claim that the original scale of CAS is a reliable and valid measure of computer attitudes, and can be confidently and effectively used by researchers. Gressard and Loyd (1986) examined and validated the components of the original scale: computer anxiety, computer confidence, and computer liking (reliability of 0.95). In addition, the original Computer Attitude Scale has been tested along with other 9 different computer attitude scales, and obtained the highest reliability measure of 0.94 , with subscales reliabilities of $0.8,0.86,0.85$ for Computer Anxiety, Computer Confidence, and Computer Liking, respectively (Woodrow, 1991). Later, a fourth subscale, labeled Computer Usefulness, with a reported reliability of 0.82, was added to the Computer Attitude Scale (Loyd and Gressard, 1986).

\subsection{Statistical Technique Used in Study}

The statistical technique employed by the researcher in the present study was as following:

1. Measure of central Tendency: Mean

2. Measure of Dispersion: Standard Deviation

3. t-test to measure the significance

\section{Analysis and Interpretation}

The main aim of present investigation is to study of ICT user and non-user Teachers attitude towards ICT in relation to their school teaching subjects. Thus, keeping in view the objectives and variables of the study in mind the data has analyzed under the following 7 sections:

\subsection{Study of the Attitude of ICT User Teachers towards ICT in Relation to Their School Teaching Subjects}

In reference to study the nature of distribution of teachers attitude scores of ICT user, mean and standard deviation values have been calculated, which are shown in table 1 .

Table 1. Mean and S.D of ICT user teachers attitude towards ICT

\begin{tabular}{|c|c|c|c|}
\hline Group & $\mathrm{N}$ & $\mathrm{M}$ & $\mathrm{S} . \mathrm{D}$ \\
\hline ICT user & 20 & 133.05 & 9.80 \\
\hline
\end{tabular}

It is clear from the above table 1 that the mean value of ICT user teachers has been found i.e. 133.05 and standard deviation of this group is 9.80 , It can be interpreted on the basis of mean values of ICT user teachers' attitude towards ICT is highly positive because all ICT users have computer training and very well know the benefits and use of ICT in teaching \& learning process. Mostly ICT users were of young age groups, updated from technological advancements, and regular access internet.

\subsection{Study of the Attitude of ICT Non-User Teachers towards ICT in Relation to Their School Teaching Subjects}

In reference to study the nature of distribution of teachers attitude scores of ICT non-user, mean and standard deviation values have been calculated, which are shown in table 2 .

Table 2. Mean and S.D of ICT non-user teacher's attitude towards ICT

\begin{tabular}{|c|c|c|c|}
\hline Group & $\mathrm{N}$ & $\mathrm{M}$ & S.D \\
\hline ICT Non-user & 20 & 122.35 & 6.00 \\
\hline
\end{tabular}

It is clear from the above table- 2 that the mean value of ICT non-user teachers has been found i.e. 122.35 and standard deviation of this group is 6.00 , It can be interpreted on the basis of mean values of ICT non- user teachers' attitude towards ICT is slightly positive. The reason behind this may be no formal training in computer is taken by ICT non-users.

\subsection{Comparison of the Attitude of ICT User and Non-User Teachers towards ICT in Relation to Their School Teaching Subjects}

In order to compare of ICT user and non-user teachers attitude towards ICT the mean, S.D, and ' $t$ '-value has been computed as given in the following table 3 .

Table 3. Mean, S.D, and ' $t$ '-value of ICT user and non-user teacher's attitude towards ICT $(\mathrm{N}=10)$

\begin{tabular}{|c|c|c|c|c|c|c|}
\hline S.No & Groups & $\mathrm{M}$ & $\mathrm{SD}$ & $\mathrm{M} 1 \sim \mathrm{M} 2$ & $\mathrm{t}$ & $\mathrm{P}$ \\
\cline { 1 - 4 } 1. & ICT Users & 133.05 & 9.80 & & & \\
\cline { 1 - 4 } 2. & $\begin{array}{c}\text { ICT } \\
\text { Non-Users }\end{array}$ & 122.35 & 6.00 & 10.7 & 4.16 & $<.01$ \\
\hline
\end{tabular}

$\mathrm{p}$ (confidence label of significance)

It is clear from table 3 and fig. 1 that there is difference in the means and S.D of ICT users and non-user teachers attitude towards ICT .In order to verify these differences against happenings ' $t$ '-test was applied . On the basis of 
' $t$ '-value, It is clear that ICT user and non-user teachers attitude towards ICT is differ in relation to their school teaching subject as ' $\mathrm{t}$ '-value is found statistically significant at 0.01 level for $18 \mathrm{df}$. Thus the null hypothesis "There is no significant difference between the attitude of ICT user and non-user teachers towards ICT in relation to their school teaching subjects" is rejected. It may be possible that mostly ICT user have proper formal training in computer but, ICT non-user doesn't have any formal training in computer they learn themselves some basic operations of the computer

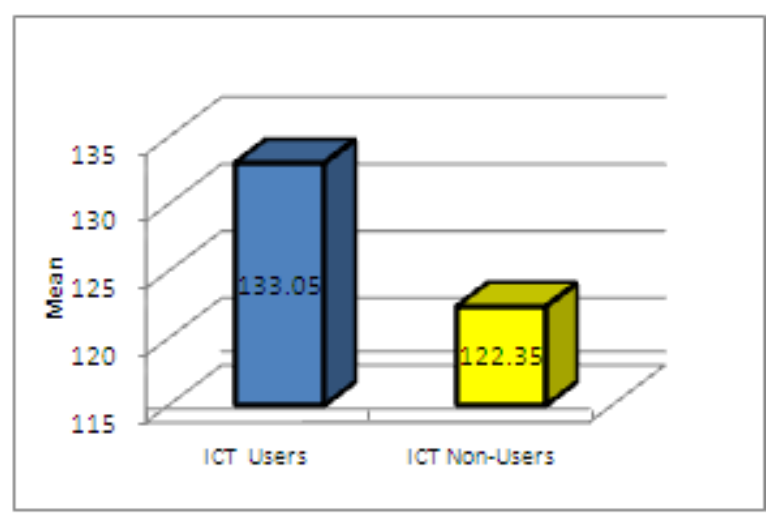

Figure 1. Mean of ICT user and non-user teachers

\subsection{Comparison of the Attitude of ICT Male and Female User Teachers towards ICT in Relation to Their School Teaching Subjects}

For comparing the attitude of ICT male and female user teachers towards ICT, the t-value for both the groups has been computed which is shown in the table -4 .

Table 4. Mean, S.D, and 't'-value of ICT male and female user teachers attitude towards ICT

\begin{tabular}{|c|c|c|c|c|c|c|}
\hline S.No & Groups & $\mathrm{M}$ & $\mathrm{SD}$ & $\mathrm{M} 1 \sim \mathrm{M} 2$ & $\mathrm{t}$ & $\mathrm{P}$ \\
\hline 1. & $\begin{array}{c}\text { ICT Male } \\
\text { Users }\end{array}$ & 127.7 & 6.46 & \multirow{2}{*}{10.7} & 2.87 & .05 \\
\cline { 1 - 4 } 2. & $\begin{array}{c}\text { ICT Female } \\
\text { Users }\end{array}$ & 138.4 & 9.879 & & & \\
\hline
\end{tabular}

$\mathrm{N}=10 . \mathrm{p}$ (confidence label of significance)

From the table- 4 and fig. 2 it is analyzed that there is statistically significant difference between the attitude of ICT male and female user teachers towards ICT. $(\mathrm{t}=2.87$, $\mathrm{p}<.05$ ), so the null hypothesis, "There is no significant difference between the attitude of ICT male and female user teachers towards ICT in relation to their school teaching subjects" has been rejected. The obtained significant difference can also be interpreted on the basis of mean values of both the groups as the mean value (138.4) of ICT female user teachers is very much higher than the mean value (127.7) of ICT male user teachers. Thus, it can be said that ICT female user teachers have more positive attitude than ICT male user teachers.

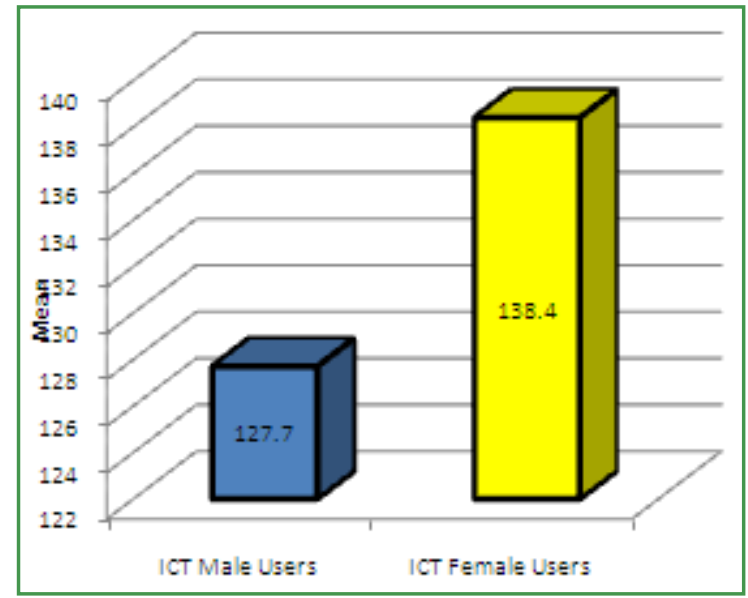

Figure 2. Mean of ICT male and female user teachers

\subsection{Comparison of the Attitude of ICT Male and Female Non-User Teachers towards ICT in Relation to Their School Teaching Subjects}

For comparing the attitude of ICT male and female nonuser teachers towards ICT, the t-value for both the groups has been computed which is shown in the table -5 .

Table 5. Mean, S.D. and ' $t$ '-value of ICT male and female non-user teachers attitude towards ICT

\begin{tabular}{|c|c|c|c|c|c|c|}
\hline S.No & Groups & $\mathrm{M}$ & $\mathrm{SD}$ & $\mathrm{M} 1 \sim \mathrm{M} 2$ & $\mathrm{t}$ & $\mathrm{P}$ \\
\hline 1. & $\begin{array}{c}\text { ICT Male Non- } \\
\text { Users }\end{array}$ & 119.8 & 5.05 & \multirow{2}{*}{5.1} & 2.06 & .05 \\
\cline { 1 - 5 } 2. & $\begin{array}{c}\text { ICT Female } \\
\text { Non-Users }\end{array}$ & 124.9 & 6.00 & & \\
\hline
\end{tabular}

$\mathrm{N}=10 \mathrm{p}$ (confidence label of significance)

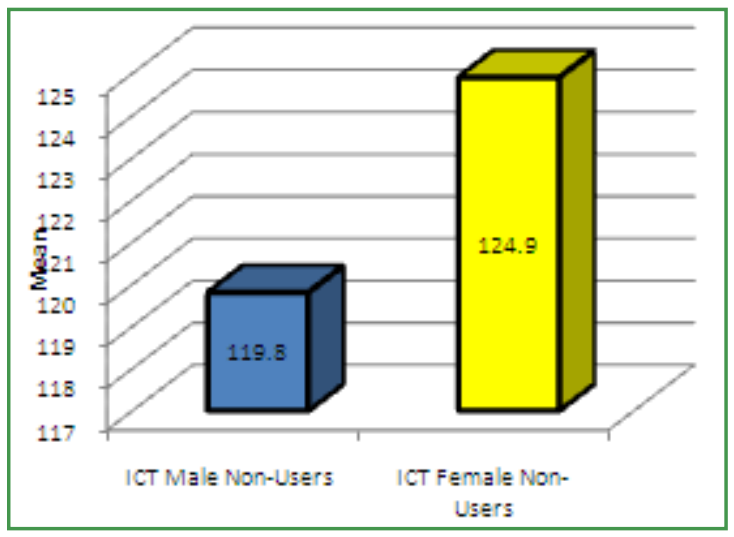

Figure 3. Mean of ICT male and female non-user teachers

From the table 5.1 and fig. 3 it is analyzed that there is no significant difference between the attitude of ICT male and female non-user teachers towards ICT in relation to their school teaching subjects as calculated t-value (2.06) is less than the table value at 0.05 level of significance. Therefore, the null hypothesis, there is no significant difference between the attitude of ICT male and female non-user teachers towards ICT in relation to their school teaching subjects is accepted. It may be possible because male \& 
female non-users teachers don't have any formal or informal computer training \& doesn't know how ICT can be use in teaching learning process. Mostly ICT non-user have long span of teaching experience and about age group of 35-50. They mostly use old methods of teaching like lecture methods.

\subsection{Comparison of Attitude of ICT User and Non-User Male Teachers towards ICT in Relation to Their School Teaching Subjects}

For comparing the ICT male user and non- user teachers attitude towards ICT, the t-value for both the groups has been computed which is shown in the table -6 .

Table 6. Mean, S.D. and ' $t$ '-value of ICT male user and non-user teachers attitude towards ICT

\begin{tabular}{|c|c|c|c|c|c|c|}
\hline S.No & Groups & $\mathrm{M}$ & $\mathrm{SD}$ & $\mathrm{M} 1 \sim \mathrm{M} 2$ & $\mathrm{t}$ & $\mathrm{P}$ \\
\hline 1. & ICT Male Users & 127.7 & 6.46 & \multirow{2}{*}{7.9} & \multirow{2}{*}{3.05} & $<.01$ \\
\cline { 1 - 4 } 2. & $\begin{array}{c}\text { ICT Male } \\
\text { Non-Users }\end{array}$ & 119.8 & 5.05 & & & \\
\hline
\end{tabular}

$\mathrm{N}=10 \mathrm{p}$ (confidence label of significance)

The above table -6 and fig. 4 shows that the mean values of teachers attitude score towards ICT obtained by two groups i.e. ICT male user and non-user, are 127.7 and 119.8 respectively; which depict that ICT male user teachers have higher mean value and subsequently indicates more positive attitude of them. The standard deviations of both the groups are 6.46 and 5.05, which indicate more deviation in ICT male user teachers group from their mean value. it is analyzed that there is statistically difference between the attitude of ICT male user and non-user teachers towards ICT. $(t=3.05$, $\mathrm{p}<.01$ ), so the null hypothesis, "There is no significant difference between the attitude of ICT male user and non-user teachers towards ICT in relation to their school teaching subjects" is rejected. Thus, it may be said that ICT male user teachers have more positive attitude than ICT male non-user teachers.

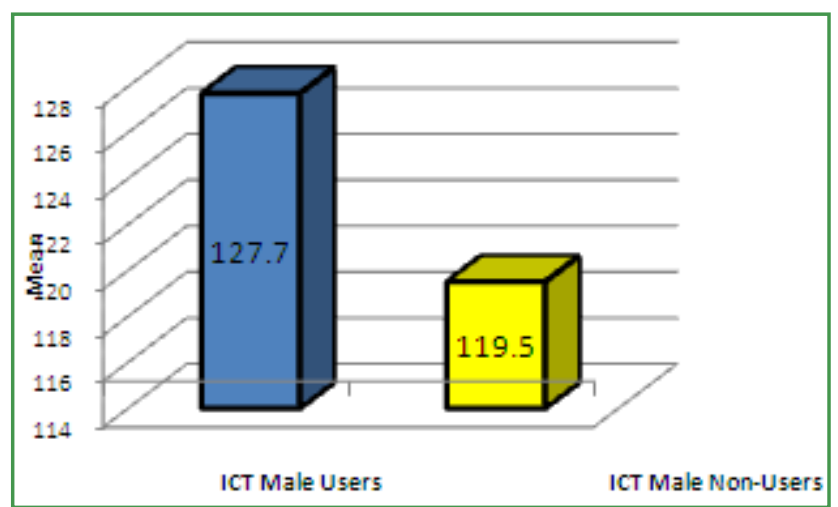

Figure 4. Mean of ICT user and non-user male teachers

\subsection{Comparison of the Attitude of ICT Female User and Non-User Teachers towards ICT in Relation to Their School Teaching Subjects}

For comparing the ICT female user and non- user teachers attitude towards ICT, M, S.D and t-value for both the groups has been computed which is shown in the table -7 .

Table 7. Mean, S.D. and ' $t$ '-value of ICT female user and non-user teachers attitude towards ICT

\begin{tabular}{|c|c|c|c|c|c|c|}
\hline S.No & Groups & $\mathrm{M}$ & $\mathrm{SD}$ & $\mathrm{M} 1 \sim \mathrm{M} 2$ & $\mathrm{t}$ & $\mathrm{P}$ \\
\hline 1. & $\begin{array}{c}\text { ICT Female } \\
\text { Users }\end{array}$ & 138.4 & 9.87 & \multirow{2}{*}{13.5} & 3.69 & $<.01$ \\
\cline { 1 - 4 } 2. & $\begin{array}{c}\text { ICT Female } \\
\text { Non-Users }\end{array}$ & 124.9 & 6.00 & & \\
\hline
\end{tabular}

$\mathrm{N}=10 \mathrm{p}$ (confidence label of significance)

The above table 7 and fig. 5 shows that the mean values of teachers attitude score towards ICT obtained by two groups i.e. ICT female user and non-user, are 138.4 and 124.9 respectively; which depict that ICT female user teachers have higher mean value and subsequently indicates more positive attitude of them. The standard deviations of both the groups are 9.87and 6.00, which indicate more deviation in ICT female user teachers group from their mean value. It is analyzed that there is statistically significant difference between the attitude of ICT female user and non-user teachers towards ICT. $(\mathrm{t}=3.69, \mathrm{p}<.01)$, so the null hypothesis, "There is no significant difference between the attitude of ICT female user and non-user teachers towards ICT in relation to their school teaching subjects" is rejected. Thus, it may be said that ICT female user teachers have more positive attitude than ICT female non-user teachers. It is found that ICT female users have computer training and computer/internet access on regular basis whereas ICT female non-users didn't have any formal or informal computer training. Mostly non users had long span of teaching experience and don't know how ICT can be use in teaching learning process.

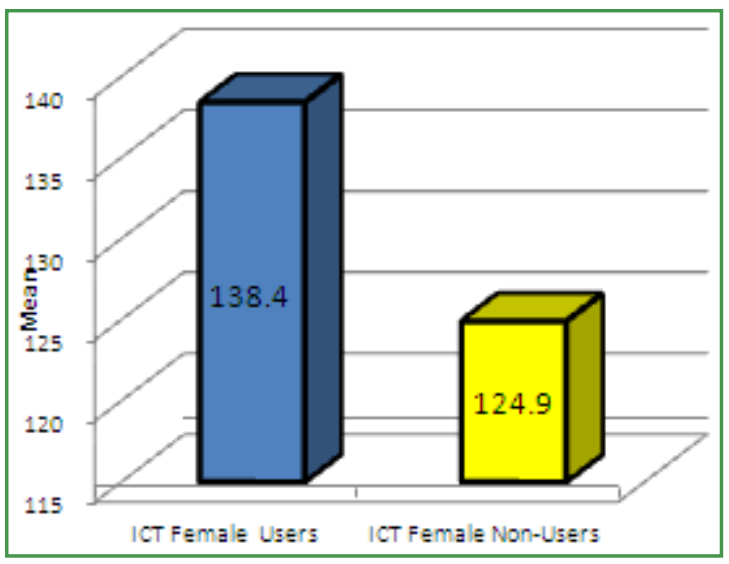

Figure 5. Mean of ICT user and non-user female teachers

\section{Conclusion}

The conclusions which have been drawn on the basis of findings are stated below.

The major purpose of the present investigation was to 
study the ICT user and non-user teachers' attitude towards ICT in relation to their school teaching subjects. In result, ICT user teachers' attitude towards ICT is highly positive in comparison to ICT non-user teachers but they have also positive attitude towards ICT in relation to their school teaching subjects. It is believed that gender would not be a factor influencing attitudes towards computers in the near future, as computers become a prevalent tool in our daily life, regardless of whether one likes to use it or not.

This research shows that the vast majority of secondary school teachers have positive attitude towards ICT in relation to their school teaching subjects for many reasons. They appeared to be aware that the computer held many benefits for them as a teacher, guide and facilitator for their students in their effective learning. Their attitudes toward this technology were positive. Although much need to be done to increase Internet use and skills among teachers, this finding proves encouraging as studies have clearly shown that the success of computer utilization was very much related to the users' attitudes toward the computer(Liaw, 2002; Moon \& Kim, 2001; Johnson \& Hignite, 2000). The tendency of those who have more positive attitudes, to use and integrate the computer in their teaching-learning process in the classrooms is very high. It is likely that they will integrate the new technology effectively in their classroom instruction as they are convinced of the benefits of the computer either as a teaching tool or as a learning medium.

The research also provides some evidence that computer experience plays a pivotal role in increasing computer use. Experienced computer users tended to remain using computer longer comfortably than those with lesser experience and non-users of computer each time they use the computer. The more experienced they were, the more likely they would use it for teaching-learning related activities compared to activities of a personal \& social nature. Minges (2003) asserted that Internet use was closely linked to education. Internet experience also encouraged positive attitudes toward the computer. The fact of teaching staff being young can provide the ICT integration due to its recent formation. Nevertheless, these teachers due to its little experience and in circumstances that they don't trust in their work and in their competences, may have fear to apply the new technologies. Due to this fact students cannot be conducted into a significant learning.

\section{REFERENCES}

[1] Cawthera, A. (2001); Computers in secondary school in developing countries: Cost and other issues. Journal of Education Planning and Administration, vol.XIX No.1.Jan05.DFID Education publication.Pp.50

[2] Kanade, H.M. (1987); Trends in CIET's Educational Television Programmes Over a four-year period, 1982-86. CIGI project NCERT, New Delhi.

[3] Kapil, H.K. (2001); Research Methodology: H.P.Bhargava Book House: Agra

[4] Saxena \& Gihar. (2009); ICT in Professional Education: APH Publishing Corporation, DaryaGang- New Delhi.

[5] Arulsamy, S \& P.Sivakumar. (2009); Application of ICT in Education: Neel Kamal Publication pvt. Ltd., Hydrabad.

[6] NCERT 2000. National curriculum framework for school education-2000, :New Delhi

[7] NCERT 2005. National curriculum framework -2005, New Delhi.

[8] Dictionary of Education (1959) IIEd. Mc. Graw-Hill Book Comp. Inc, London.

[9] Anderson, Robert H. and Bikson, Tora K. (1998) Focus on Generic Skills for Information Technology Literacy. Paper presented at Information Technology Literacy Workshop, Irvine, California, January 14-15.

[10] Huang, H. M., \& Liaw, S. S. (2005). Exploring users' attitudes and intentions toward the Web as a survey tool. Computers in Human Behavior. 21(5), 729-743.

[11] Sorgo, A., Verckovnik, T. and Kocijancic, S. (2009) Information and Communication Technologies (ICT) in Biology Teaching in Slovenian Secondary Schools Eurasia Journal of Mathematics, Science \& Technology Education, 2010, 6(1), 37-46.

[12] Bawden, D. (2001). Information and digital literacy: A review of concepts. Journal of Documentation, 57(2), 218-259.

[13] Bell, R., Bell, L. (2003). A bibliography of articles on technology in science education. Contemporary Issues in Technology and Teacher Education, 2(4), 427-447.

[14] Wang, Y. (2002). When technology meets beliefs: Pre-service teachers' perception of the teachers' role in the classroom with computers. Journal of Research on Technology in Education, 35(1), 150-162.

[15] Osodo, J., Indosi, F.C. \& Ongati,O.(2010); Attitudes of students and teachers towards use of computer technology in Geography education, Educational Research Vol. 1(5) pp. 145-149 June 2010, Available online http://www.interesjournals.org/ER. 